\title{
SELF-ESTEEM OF MANAGER IN THE LIGHT OF DECLARATIVE RESEARCH
}

\begin{abstract}
This article is an introduction to a wider research project aimed at analyzing managers' self-esteem in context of their personality, cognitive and social competency determinants. Adequate self-esteem is critical for managers effective performance. There are significant differences between high and low self-esteem in terms of persistence and activity levels. Self-esteem persons face openly challenges while the low self-esteem ones are primarily oriented towards avoiding failure. Self-esteem is also associated with susceptibility to risk and decision-making in management. Although it has been the subject of research for more than one hundred years few reliable measurement tools are available.

In the present study an attempt was made to determine which personality and social competency variables are significant predictors of self-reported self-esteem. Ninety researched subjects were working either for corporations or SME sector as managers. Rosenberg Self-Esteem Scale, NEO-FFI (personality factors) by Costa, McCrae, and the Social Competency Profile by Matczak and Martowska were used. Curvilinear relationship between self-esteem and age was found. Contrary to expectations women did not score higher on self-esteem than males. Hierarchical stepwise regression analysis revealed neuroticism as major and social resourcefulness as a secondary significant variable explaining self-esteem in Polish managers.
\end{abstract}

Keywords: explicit and implicit self-esteem, managers, Poland.

\section{INTRODUCTION}

The pace of civilization changes in the modern world, the competitive market, the rapidly growing technological progress transform drastically the organization of work and the structure of enterprises, and thus the functioning and manner of operation of managers. Still present post-communist heritage of tough management style combined with the challenges promote self-confident, effective boss. High self-esteem remains a key requirement for the manager's job in Poland. At the same time, as research shows in the world of high volatility and uncertainty (VUCA) democratic, much softer management styles are increasingly

\footnotetext{
${ }^{1}$ Agata Gierczak, PhD, Faculty of Management, Rzeszow University of Technology, Poland, Al. Powstańców Warszawy 8, 35-959 Rzeszow (Author for correspondence: e-mail: agatag@prz. edu.pl)

2 Piotr Olaf Żylicz, Associate Professor, Department of Management, Faculty of Arts and Social Sciences, SWPS University of Social Sciences and Humanities, Chodakowska 19/31, 03-815 Warsaw, e-mail: ozylicz@swps.edu.pl
} 
needed ${ }^{3}$. We have no data to answer the question how often behind the facade of an unshakable Polish boss low self-esteem, narcissistic personality disorder, workaholism or even depression are hidden. We still know little on mechanisms working in the minds of these managers to maintain a good self-image, how tough they really are, whether their explicit and implicit self-esteem are congruent. Do they use specific defense mechanisms and what level of social approval is characteristic for them?

This article is an introduction to a wider research project aimed at finding answers to the above questions. At the first stage, psychological determinants - personality variables and social competences - were analyzed as predictors of the explicit self-esteem in a group of Polish managers.

\section{SELECTED THEORIES EXPLAINING SELF-ESTEEM}

In management psychology, self-esteem is of particular importance because it is critical for success and creative, ambitious actions in the organization. Baumeister and Leary in their concept assumed that self-esteem is the indicator of the current acceptance of the individual by its social environment ${ }^{4}$. To simplify, satisfying relationships with others are a prerequisite for positive self-esteem, taking into account the huge number of studies that confirm the strong need for belonging to people and the need for social ties. Mark Leary attributes self-esteem two tasks in a function of a sort of sociometer: monitoring social environment in search of signals of rejection or exclusion by others, and internal signaling the individual through the negative affective response ${ }^{5}$. Denissen and associates demonstrated the correlation between quantity and quality of social interaction with self-esteem.

In the management process manager's self-esteem is of particular importance; Baumeister showed significant differences between individuals with high and low self-esteem in the level of persistence and activity ${ }^{6}$. People with high self-esteem are more persistent and take more initiative, they are more active and engaged than those with low self-esteem. It was also shown that people with high self-esteem set goals for challenges, while those with low self-esteem were primarily oriented towards avoiding failure ${ }^{7}$.

The success of a modern manager strongly depends on their capabilities to make decision and manage properly risk. It is related to self-esteem. When high self-esteem is uncertain or threatened, it induces a risky activity ${ }^{8}$. This risky behavior may be due to the strong motivation of these individuals to develop self-esteem ${ }^{9}$, especially as they tend to have

3 Aon Hewitt (2015). Aon Global Risk Management Survey.

${ }^{4}$ R.F. Baumeister, M.R. Leary, The nature and function of self-esteem: Sociometer theory, "Advances in experimental social psychology" 2000, Vol. 32, 1-62.,

5 M.R. Leary, Sociometer theory and the pursuit of relational value: Getting to the root of self-esteem, "European Review of Social Psychology" 2005, 16, 75-111.

${ }^{6}$ R.F. Baumeister, J.D. Campbell, J.I. Krueger, K.D. Vohs, Does high self-esteem cause better performance, interpersonal success, happiness, or healthier lifestyles?, "Psychological Science in the Public Interest" 2003, 4(1), 1-44.

7 S.A. Heimpel, A.J. Elliot, J.V. Wood, Basic personality dispositions, self-esteem, and personal goals: An approach-avoidance analysis, "Journal of Personality" 2006, 74, 1293-1319.

8 R.F. Baumeister, L. Smart, J.M. Boden, Relation of threatened egotism to violence and aggression: The dark side of self-esteem, "Psychological Review" 1996, 103, 5-33.

9 D.M. Tice, The social motivations of people with low self-esteem [w:] R.F. Baumeister (ed.), Selfesteem. The puzzle of low self-esteem, New York 1993, 37-53. 
a positive self-presentation in social situations ${ }^{10}$. It gives an opportunity to confirm yourself. People with low self-esteem tend to be less likely to take risks, focus on their shortcomings, avoid strategic tactics, and display a reluctance to focus on others ${ }^{11}$. They prefer safe and neutral situations, even at the expense of potential success. Their self-image is inconsistent and unclear, they are susceptible to injury in threatening situations and have difficulty coping with adversities. As a result, they tend to withdraw from stressful situations ${ }^{12}$. In people with high self-esteem withdrawing from the activity is usually linked with their rational assessments and resultant decisions ${ }^{13}$. The level of determination, persistence in pursuit of goals and degree of commitment are strongly differentiating managers with high and low self-esteem.

Polish psychologists developed the notion of the ideal self derived from William James concept of 'I' and 'Me' which gave rise to the motivation theory dwelling on discrepancy between the real and the ideal. It was assumed that both the real self and the perfect self can function as a regulatory standard, but depending on which prevails, one can expect behaviors aimed at defending self, maintaining self, or expanding self, auto-creation or self-reliance ${ }^{14}$.

The idea of divergence in the self in Tory Higgins system is of great value for selfesteem research - the divergence between the ideal and the real conception of ourselves and between the real and the duty concept of own person ${ }^{15}$. In this ideal self approach, it is a desirable image of one's self constructed on the basis of one's own desires or expectations. Self, on the other hand, is a set of expectations towards myself as well as the demands of society. By real self we understand a man as he really is. Higgins shows the relationship between the type of discrepancy and the emotion that occurs - the continuation of the discrepancy between the real and the ideal one entails a feeling of disappointment towards oneself, sadness and dissatisfaction, whereas the incompatibility between the real and the ideal causes shame, fear and embarrassment. Identification of these emotions is important in the context of motivation ${ }^{16}$.

${ }^{10}$ R.F. Baumeister, D.M. Tice, D.G. Hutton, Self-presentational motivation and personality differences in self-esteem, "Journal of Personalit" 1989, 57, 547-579.

11 J.D. Campbell, L.F. Lavallee, Who am I? The role of self-concept confusion in understanding the behavior of people with low self-esteem [w:] R.F. Baumeister, (ed.), Self-esteem..., 3-20.

12 Ibidem

13 A. Di Paula, J.D. Campbell, Self-esteem and persistence in the face of failure, "Journal of Personality and Social Psychology" 2002, 83, 711-724.

14 J. Karyłowski, O dwóch typach altruizmu, Wrocław 1982; W. Łukaszewski, Struktura ja a działanie w sytuacjach zadaniowych: empiryczne studium nad funkcjami osobowości, Acta Universitatis Wratislaviensis, No 415, Wrocław 1978; J. Reykowski, G. Kochańska, Szkice z teorii osobowości, Warszawa 1980; J. Reykowski, O.W. Owczynnikowa, K. Obuchowski (red.), Studia z psychologii emocji, motywacji i osobowości, Wrocław 1977; B. Wojciszke, Struktura "ja”, wartości osobiste a zachowanie, Wrocław 1986.

15 E.T. Higgins, Self-discrepancy: A theory relating self and affect, "Psychological Review" 1987, Vol. 94(3), 319-340; E.T. Higgins, C.J.R. Roney, E. Crowe \& C. Hymes, Ideal versus ought predilections for approach and avoidance distinct self regulatory systems, "Journal of Personality and Social Psychology" 1994, 66(2), 276-286.

${ }^{16}$ E.T. Higgins, Self-discrepancy..., 319-340. 
The occurrence of discrepancies in the self system causes different feelings and different actions of the individual; the aim is to reduce divergence in the self system ${ }^{17}$. The fewer discrepancies, the fewer internal conflicts and the more effective functioning of a person, especially the manager.

Self-esteem reflects greater possibilities of own action ${ }^{18}$. People with more favorable temperamental patterns (low activity and high persistence) tend to have positive selfesteem. Self-esteem determines the level of activity of the individuals and their emotions. It allows to look at the direction of affectiveness and activity level ${ }^{19}$. The study of these authors and others showed that people with high self-esteem experienced more positive emotions and were more active and persistent than those with low self-esteem ${ }^{20}$. Also in the aspect of perceiving oneself in the area of task and social functioning, the self-assessors will have a better self-image.

For Carr self-esteem lies at the core of self-efficacy. "The beliefs about self-efficacy improve the functioning of the immune system ... they lead to greater resistance to stress and better psychological and social adaptation." Under Carr's concept "high self-esteem and strong conviction of self-efficacy, ... form personal strength and resilience" ${ }^{21}$.

Bandura in his theory of personal effectiveness, presents his own position about performing, organizing tasks while achieving goals. The major sources of self-efficacy are observational experiences (e.g. I am better than others), internal locus of control, social persuasion, but also emotional and physical condition ${ }^{22}$.

A juxtaposition of concepts of Polish researchers on self-esteem seems strongly relevant. Strelau wrote "Self-esteem is the evaluation of the notion of self, i.e. a generalized or persistent evaluation of oneself as a person" and "Self-esteem is an affective reaction of man to himself" 23 . Like other mostly affective reactions, self-esteem can be characterized by both "hot", intense emotions, and "cold" judgment ${ }^{24}$. Self-esteem can be considered in terms of either: (1) a relatively lasting property of the person's mind, (2) situational personal characteristic, or (3) the need to maintain good judgment about oneself. A number of mechanisms to sustain positive self-esteem, including the formulation of flattering judgments about oneself, social comparison, self-affirmation and self-presentation ${ }^{25}$. Need for social approval was found strongly linked to the need for positive self-esteem.

Explicit self-esteem, which is measured by the Rosenberg scale (see below), should be distinguished from the implicit one that shows latent attitude towards self. It is impossible to introspectively identify the impact of attitudes toward oneself on the evaluation of objects

${ }^{17}$ P.K. Oleś, Wprowadzenie do psychologii osobowości, Warszawa 2008.

${ }^{18}$ K. Lachowicz-Tabaczek, J. Śniecińska, Intrapsychiczne źródła samooceny: znaczenie emocji, temperamentu i poczucia zdolności do działania, „Czasopismo Psychologiczne” 2008, 2, 229-246.

19 M. Łaguna, K. Lachowicz-Tabaczek, I. Dzwonkowska, Skala samooceny SES Morrisa Rosenberga - polska adaptacja metody, „Psychologia Społeczna” 2007, t. 202 (04) 164-176.

${ }^{20}$ R.F. Baumeister, L. Smart, J.M.Boden, Relation of threatened egotism to violence and aggression: The dark side of self-esteem, "Psychological Review" 1996, 103, 5-33.

21 A. Carr, Psychologia pozytywna. Nauka o szczęściu i ludzkich siłach, Poznań 2009.

22 A. Bandura, Self-Efficacy: The Exercise of Control, New York 1997.

23 J. Strelau (ed.), Psychologia. Podręcznik akademicki, t. I, Gdańsk 2000.

24 J. Strelau, D. Doliński (ed.), Psychologia akademicka. Podręcznik, Vol. I, Gdańsk 2015.

25 J. Strelau, D. Doliński (ed.), Psychologia akademicka. Podręcznik. Vol. II, Gdańsk 2015. 
related to self and those not related ${ }^{26}$. Implicit self-esteem is a hidden attitude towards self, i.e., an affect with self. Ideally, it should be free of the need for social approval, the tendency to make a good impression, fear of evaluation, self-deception and self-empowerment ${ }^{27}$. Implicit self-esteem explains a spontaneous affect in everyday $\operatorname{life}^{28}$.

\section{OVERVIEW OF SELF-ESTEEM MEASSUREMENT METHODS}

Although researchers have been working on self-esteem and have been trying to investigate it for more than 100 years (since William James), we still do not have methods to measure it accurately. Series of research shows the limitations and biases of self-reports methods in assessment of self-esteem. One of the most commonly used methods measuring self-esteem, among others due to its simplicity, while at the same time of high reliability and accuracy, is the Self-Esteem Scale (SES) developed by Morris Rosenberg, in Polish adaptation by Łaguna, Lachowicz-Tabaczek and Dzwonkowska (2007) ${ }^{29}$. A ten-item questionnaire examines the general level of personal self-esteem. In Rosenberg's definition (1965) "Self-esteem is a positive or negative attitude towards me, a kind of global selfassessment. High self-esteem is the belief that you are "good enough," a valuable person, and low self-esteem means dissatisfaction with yourself, a kind of rejection of yourself".

In Poland the Multidimentional Self-Esteem Inventory (MSEI) by O'Brien and Epstein (1988) in the adaptation by Fecenec (2008) has been also applied ${ }^{30}$. It consists of 11 scales - nine of which cover self-esteem with related aspects: its global level and eight components such as: Competence, Lovability, Likability, Personal Power, Self-Control, Moral Self-Approval, Body Appearance, and Body Functioning.

While explicit self-esteem explains anxiety in declarative research, in turn the aforementioned implicit self-esteem accounts for by the behavioral symptoms of anxiety ${ }^{31}$. Rudolph, Schröder-Abé, Riketta and Schütz showed that implicit self-esteem could predict observed and spontaneous behavior, but did not predict a controlled behavior ${ }^{32}$.

${ }^{26}$ J.K. Bosson, Assessing self-esteem via self-reports and nonreactive instruments: Issues and recommendations. [In:] M. Kernis (Ed.), Self-esteem issues and answers: A sourcebook of current perspectives, pp. 88-95. London 2006; A.G. Greenwald, M.R. Banaji, Utajone poznanie spoteczne: postawy, wartościowanie siebie i stereotypy, „Przegląd Psychologiczny” 1995, 38 (1), 11-63; A.G. Greenwald, S.D. Farnham, Using the Implicit Association Test to Measure Self-Esteem and Self-Concept, "Journal of Personality and Social Psychology" 2000, Vol. 79, No 6, 1022-1038.

27 A. Fila-Jankowska, Samoocena autentyczna. Co ukrywamy sami przed soba, Warszawa 2009.

28 T. Conner, L.F. Barrett, Implicit Self-Attitudes Predict Spontaneous Affect in Daily Life, "Emotion" 2005, Vol. 5 (4), 476-488.

${ }^{29}$ M. Łaguna, K. Lachowicz-Tabaczek, I. Dzwonkowska I., Skala samooceny SES Morrisa Rosenberga - polska adaptacja metody, „Psychologia Społeczna” 2007, t. 202 (04) 164-176.

${ }^{30}$ E.J. O'Brien, S. Epstein, D. Fecenec, MSEI: Wielowymiarowy Kwestionariusz Samooceny MSEI, Warszawa 1988.

${ }^{31}$ L.R. Spalding, C.D. Hardin, Unconscious unease and self-handicapping: Behavioral consequences of individual differences in implicit and explicit self-esteem, "Psychological Science" 1999, 10, 535-539.

32 A. Rudolph, M. Schröder-Abé, M. Riketta, A. Schütz, Easier when done than said! Implicit selfesteem predicts observed or spontaneous behavior, but not self-reported or controlled behavior, "Journal of Psychology" 2010, 218,12-19. 
It is assumed that implicit and explicit self-esteem is a various manifestation of attitudes toward oneself and does not have to be compatible ${ }^{33}$. Implicit and explicit ratings are weakly correlated; As a rule, this correlation does not exceed $0,25^{34}$. Unfortunately, tools used to investigate implicit self-esteem are questioned in terms of their validity and relaibility. The Implicit Association Test (IAT) ${ }^{35}$, as well as the preference for the first name and last name, and the date of birth ${ }^{36}$ have been employed as relatively the most reliable tools for implicit self-esteem. Projective tests, verbal and drawing techniques are also used. However, there is still too little replication of the tools usage on larger scale.

\section{DESCRIPTION OF THE RESEARCH AND RESULTS}

The aim of the study

The results of the research presented in this paper are a part of a wider research plan aimed at analyzing the manager's functioning in relation to the quality of their self-esteem and personality, cognitive and competence conditioning. As both observations and high publicity studies suggest, the global manager self-esteem declared in the study may be, as previously reported, uncorrelated with implicit self-esteem. In the presented research used as preliminary one, an attempt was made to determine which personality and competence variables were the best predictors of explicit self-esteem in order to better understand the psychological nature of self-esteem in managers.

\section{Characteristics of the study group}

The research was conducted in a group of 120 managers. Ninety correctly filled questionnaires $(\mathrm{N}=90)$ returned. The research sample consisted of mid-level corporate managers (59 persons) and managers of the SME sector (Small and Medium-Sized Enterprises) (31 persons); 61 men and 29 women. The study was conducted at the turn of the years $2014 / 2015$.

\section{Variables and research tools}

- global self-esteem level - measured by the Self-Esteem Scale in the Polish adaptation $^{37}$. The scale allows to evaluate a relatively stable disposition understood as a conscious attitude (positively or negatively) towards self. The scale consists of 10 statements of a diagnostic character. The answers are given on a four-level scale from 1 to 4 (1 - I strongly agree, 4 - I strongly disagree). From each response one can score from 1 to 4 points, so the test taker can get from 10 to 40 points. The higher

33 A.G. Greenwald, M.R. Banaji, L.A. Rudman, S.D. Farnham, B.A. Nosek, D.S. Mellott, A unified theory of implicit attitudes, stereotypes, and self-concept, "Psychological Review" 2002, 109, $3-25$.

${ }^{34}$ J.K. Bosson, W.B. Swann, J.W. Jr., Pennebaker, Stalking the perfect measure of implicit self-esteem: The blind men and the elephant revisited?, "Journal of Personality and Social Psychology" 2000, 79, 631-643.

35 To date studies allowed to measure the reliability of this test: $\alpha$ Cronbach $-0,88$ (Bosson, Swann and Pennebaker, 2000), Spearman-Brown - 0,61-0,73 (Jordan, Whitfield and Zeigler-Hill, 2007), Test-retest - 0,52-0,69 (Greenwald and Farnham, 2000).

36 J.K. Bosson, W.B. Swann, J.W. Jr., Pennebaker, op. cit., 631-643.

${ }^{37}$ I. Dzwonkowska, K. Lachowicz-Tabaczek, M. Łaguna, Samoocena i jej pomiar. Polska adaptacja skali SES M. Rosenberga. Podręcznik, Warszawa 2008. 
the score, the higher the self-esteem. The reliability of the Polish version of the scale estimated by the Cronbach alpha coefficient is high, ranging from 0,81 to 0,83 (in different standardization groups, in the $\mathrm{N}=1121$ test).

- the personality traits of managers have been measured using the NEO-FFI by Costa and McCrae (Polish adaptation of Zawadzki, Strelau, Szczepaniak, Śliwińska) ${ }^{38}$. The five main factors are neuroticism, extraversion, openness to experience, agreeableness and conscientiousness. Cronbach's internal alpha coefficient, which is a measure of the reliability of the test, was highest for the Neuroticism - 0,82, Agreeableness $-0,80$ and Extraversion - 0,77 . A slightly lower score was obtained for Openness to experience - 0,68 and Consciousness - 0,68.

- social competencies of managers, that is a set of acquirable skills needed for successful social adaptation and effective functioning while with other people. They have been measured by the PROKOS test, (Social Competency Profile) by Matczak and Martowska with 5 scales covering assertive skills, cooperative skills, sociability, community-mindedness, and social resourcefulness ${ }^{39}$. Diagnostic items consist of five scales created on the basis of the factor analysis. The questionnaire is reliable and can be used for research and individual diagnosis; Cronbach's alpha coefficients are over 0,90 .

\section{Results analysis}

\section{Age, sex and type of organization vs. explicit self-esteem}

It was assumed that older people would have lower self-esteem than younger ones. Four age groups were considered: up to 30 years old, 39 years old, 49 years old and up to 50 years old. The correlations were intriguing (Table 1).

Table 1. Person correlations of Explicit self-esteem with age within four age cohorts of managers

\begin{tabular}{|c|c|c|c|}
\hline $\begin{array}{c}\text { 1. Age }<31 \\
(\mathrm{~N}=9)\end{array}$ & $\begin{array}{c}\text { 2. Age 31-39 } \\
(\mathrm{N}=47)\end{array}$ & $\begin{array}{c}\text { 3. age 40-49 } \\
(\mathrm{N}=19)\end{array}$ & $\begin{array}{c}\text { 4. Age > 49 lat } \\
(\mathrm{N}=15)\end{array}$ \\
\hline$-0,24$ & 0,22 & -0.47 & $-0,35$ \\
\hline
\end{tabular}

Source: own research.

It turned out that only within the 31-39 age group an increase in explicit self-esteem was identified with age, whereas in the other groups the relationships were negative. Small subgroup sizes allowed some Fisher test comparisons. The test usage revealed that the differences between the correlation coefficient for group 2 and the correlation coefficients for groups 3 and 4 were statistically significant $(Z=2,15, p<0,01$ and $Z=1,81 p<0,05$, respectively). For groups 3 and 4 such statistically significant differences were not found. The group 1 was too small in size.

In turn, women on managerial positions $(N=21)$ were expected to have lower selfesteem than men managers $(N=69)$. The differences proved completely insignificant.

\footnotetext{
${ }^{38}$ P.T. Costa, R. McCrae and B. Zawadzki, J.Strleau, P. Szczepaniak, M. Śliwińska, NEO-FFI Inwentarz Osobowości NEO-FFI, Warszawa 1998.

${ }^{39}$ A. Matczak, K. Martowska, PROKOS - Profil Kompetencji Społecznych, Warszawa 2013.
} 
As expected, managers in corporations scored higher on self-esteem than those in management positions of small and medium-sized enterprises: $F(1,88)=5,71, p<0,05$, $e t a^{2}=0,06$.

\section{Relationships between personality traits and social competencies and self-esteem}

In order to explore deep interdependence between self-esteem and personality and social competence an exploratory factor analysis was conducted. An analysis of the main components (Table 2) allowed to distinguish three components. Because agreeableness was completely independent of the other variables, the results below were only shown for the once again analysis of the main components without this variable. In the first group (component 1) of variables, all social competences and extravagance and openness to experience were all significant.

Table 2. Matrix of rotated components for personality traits, social competencies and self-esteem

\begin{tabular}{|l|c|c|}
\hline \multirow{2}{*}{} & \multicolumn{2}{|c|}{ Component } \\
\cline { 2 - 3 } & 1 & 2 \\
\hline Sociability & $\mathbf{0 , 8 5}$ & 0,34 \\
\hline Community-mindedness & $\mathbf{0 , 7 7}$ & 0,33 \\
\hline Resourcefulness & $\mathbf{0 , 7 5}$ & 0,47 \\
\hline Co-operativeness & $\mathbf{0 , 7 4}$ & 0,53 \\
\hline Assertiveness & $\mathbf{0 , 6 4}$ & 0,55 \\
\hline Extraversion & $\mathbf{0 , 6 4}$ & 0,52 \\
\hline Openness to experience & $\mathbf{0 , 6 1}$ & \\
\hline Neuroticism & & $\mathbf{- 0 , 8 4}$ \\
\hline Self-esteem & & $\mathbf{0 , 8 0}$ \\
\hline Conscientiousness & & $\mathbf{0 , 7 6}$ \\
\hline
\end{tabular}

Method of extracting factors - Main components. Rotation method - Varimax with Kaiser normalization. Italics - social competences; Factors above 0,30 were considered.

Source: own research.

The above analysis reveals that all social competences load positively on a factor with extraversion and openness to experience. In turn the explicit self-esteem as measured by Rosenberg's tool forms one factor with conscientiousness and neuroticism, the latter has a negative loading on the factor. It is noteworthy that all social competences have their highest factor loadings on the first component, but on the second component they load above 0,30 . extraversion, unlike openness to experience, has a strong charge for the second component $(0,52)$.

\section{Personality and competence predictors of explicit self-esteem}

In searching for significant predictors of self-esteem stepwise regression analysis was performed, first for competence variables, and then also for personality variables (as shown by the $F$ tests, both analyzes were interpretable). 
Table 3. Coefficients for stepwise regression analysis of self-esteem on social competencies $(N=90)$

\begin{tabular}{|l|l|c|c|c|c|c|}
\hline \multirow{2}{*}{\multicolumn{2}{|c|}{ Model }} & \multicolumn{2}{|c|}{$\begin{array}{c}\text { Non-standardized } \\
\text { coefficients }\end{array}$} & $\begin{array}{c}\text { Standardized } \\
\text { coefficients }\end{array}$ & \multirow{2}{*}{$t$} & \multirow{2}{*}{$\begin{array}{c}\text { Signifi- } \\
\text { cance }\end{array}$} \\
\cline { 3 - 5 } & B & Standard error & Beta & & \\
\hline Step 1 & Resourcefulness & 0,56 & 0,08 & 0,58 & 6,67 & $<0,005$ \\
\hline \multirow{2}{*}{ Step 2 } & Resourcefulness & 0,38 & 0,12 & 0,40 & 3,148 & 0,002 \\
\cline { 2 - 5 } & Assertiveness & 0,23 & 0,12 & 0,25 & 2,008 & 0,048 \\
\hline
\end{tabular}

Source: own research.

The resourcefulness accounts for by $33 \%$ of the self-esteem variance, and the introduction of the second assertiveness step increases the explained variance up to $35 \%$.The second step regression analysis was hierarchical (Table 4). First introduced a block of personality variables, more primitive, and then a block of competence variables.

Table 4. Coefficients for hierarchical stepwise regression of self-esteem on personality factors and social competencies $(N=90)$.

\begin{tabular}{|c|c|c|c|c|c|c|}
\hline & \multirow{2}{*}{ Model } & \multicolumn{2}{|c|}{$\begin{array}{l}\text { Non-standardized } \\
\text { coefficients }\end{array}$} & \multirow{2}{*}{$\begin{array}{c}\begin{array}{c}\text { Standardized } \\
\text { coefficients }\end{array} \\
\text { Beta }\end{array}$} & \multirow{2}{*}{$t$} & \multirow{2}{*}{$\begin{array}{l}\text { Signifi- } \\
\text { cance }\end{array}$} \\
\hline & & B & $\begin{array}{l}\text { Standard } \\
\text { error }\end{array}$ & & & \\
\hline 1 & Neuroticism & $-0,44$ & 0,05 & $-0,70$ & $-9,10$ & $<0,0005$ \\
\hline \multirow{2}{*}{2} & Neuroticism & $-0,37$ & 0,06 & $-0,58$ & $-6,54$ & $<0,0005$ \\
\hline & Extraversion &, 131 & 0,06 & 0,21 & 2,295 & 0,02 \\
\hline \multirow{3}{*}{3} & Neuroticism & $-0,33$ & 0,05 & $-0,53$ & $-6,10$ & $<0,0005$ \\
\hline & Extraversion & 0,03 & 0,06 & 0,04 & 0,43 & n.s. \\
\hline & Resourcefulness & 0,2 & 0,09 & 0,30 & 3,11 & 0,003 \\
\hline
\end{tabular}

Source: own research.

Personality variables alone account for a total of $50 \%$ of self-esteem variability, with neuroticism as high as $48 \%$ (the lower neuroticism the higher self-esteem). Adding the competency variables increased the explained variance by $5 \%$. The only competence variable that increased the variance explained after the introduction of personality variables was the resourcefulness in social situations, which at the same time caused extravagance to lose independent predictive value.

The interesting interaction effect was also identified $(F=5,57, p=0,21)$. It turned out that the impact of neuroticism on the variability of self-esteem is varied depending on the level of resourcefulness. 


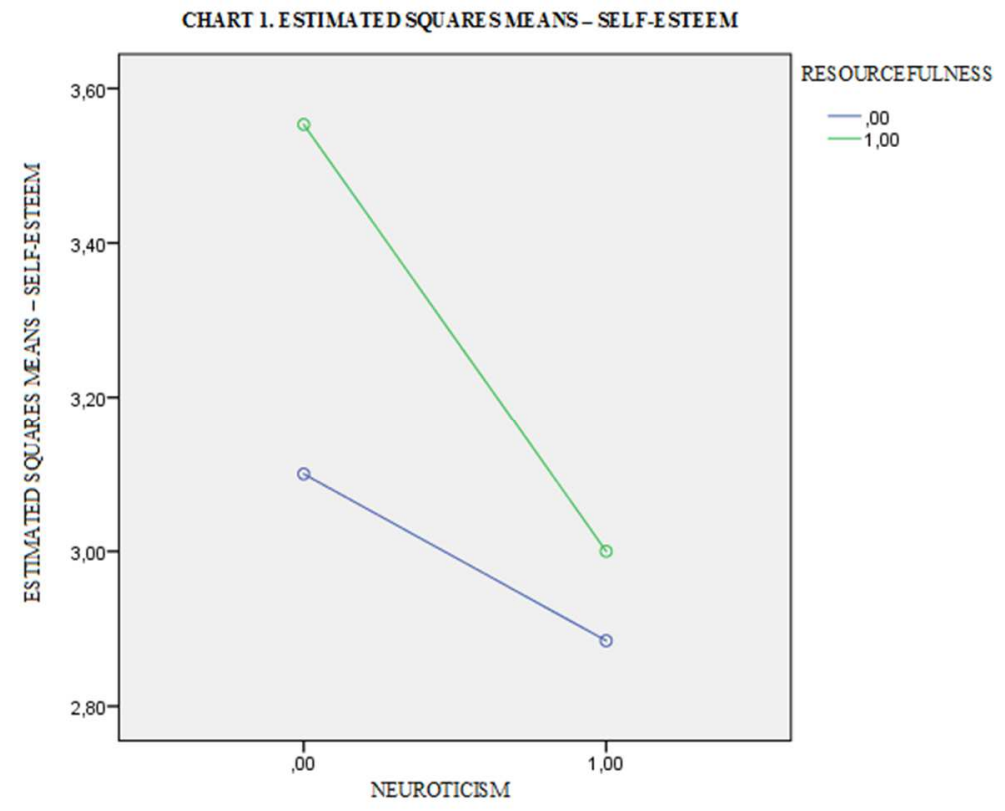

Chart 1. Estimated square means - self-esteem

Source: own research.

As the Graph 1 reveals an influence of resourcefulness in social situation on self-esteem is significantly weaker when neuroticism is high as compared with its low levels.

\section{Discussion of results}

Age relationships with explicit self-esteem were quite surprising due to the fact that in people under 30 years of age, explicit self-esteem declined as in groups of managers over the age of 40, unlike individuals in the 31-39 age range, where these dependencies, though weak, were positive. It is difficult to explain the reasons for this somewhat significant curvilinear differentiation (it was generally expected that younger people would have higher self-esteem). Certainly the relationship between age and explicit self-esteem deserves a further and deeper analysis taking into account the specificity of the generation, organizational culture and a type of an organization.

Often in diagnoses made for the needs of organizations, especially in multi-source assessments (so-called 360), women are more likely to score lower on self-esteem than men. Here, the comparisons made for general explicit self-esteem did not show any significant differences. And this time, the question of the relationship between generalized explicit selfesteem and the self-esteem in the professional context and gender in Polish managers should be further examined and analyzed, with particular emphasis on its adequacy and stability.

As expected, explicit self-esteem of managers working in corporations is higher than those employed in small and medium-sized enterprises. At the same time, we do not have the premise to postulate whether this is the result of the way people choose to work for corporations or rather to reinforce the self-esteem of the impact of such organizations. 
In turn, the results of the analysis of the main components carried out for personality factors, social competences and self-esteem allowed to formulate several conclusions. First, generalized self-esteem, as measured by Rosenberg's questionnaire, is more strongly associated with personality variables than competence ones. Self-esteem is particularly strongly associated with neuroticism (negatively) as measured by NEO-FFI. A closer analysis of the questions of this tool shows that some of them directly refer to generalized self-esteem (e.g. "I often feel worse than others" or "Sometimes I feel completely worthless", which, according to what the various authors postulate, allows to treat self-esteem as the component of neuroticism. On the other hand, together with self-esteem and neuroticism within one component conscientiousness also appeared, which also refers to tendencies of self-esteem, both indirectly through the prism of the quality of one's own behavior, and directly in a generalized manner, although regarding the specific domain of our own activities, which is shown by the question of scale (e.g. "I try to do the job assigned to me conscientiously", "When I commit myself to something, one can always rely on me" or "I am an efficient person who always finishes what she started"). The finding confirms distinction proposed by Reece and associates (2010). They proposed self-respect and self-efficacy as facets of the self-esteem. It is worth noticing that in the Lewis Goldberg circular model ${ }^{40}$ a combination of high conscientiousness and low neuroticism (emotional stability), as so-called lower-level features are called Cool-Headedness. The results obtained are consistent with the self-esteem relationships with other personality variables, as is shown in the research by Łaguna and co-workers ${ }^{41}$.

At the same time, the relatively high factor loadings (although the second largest) of the competency variables for self-esteem, neuroticism and conscientiousness suggest that it may be regarded as some sort of social competence, and as such may be at least partially learned.

Looking for independent and relevant personality and competence predictors of selfesteem measured by Rosenberg's tool, it was found that neuroticism was again crucial (the higher it is, the lower self-esteem), and resourcefulness in social situations that turned out to be more important than extraversion in explaining variablity of self-esteem. High resourcefulness helps build a person's sense of self-efficacy, which in turn promotes the generalization of positive self-esteem. The study also identified an interesting, but somewhat mysterious in nature, effect of the interaction effect of these two variables on self-esteem. It has turned out that the impact of high resourcefulness on self-esteem was moderated by neuroticism. It wae significantly lower when neuroticism is high than when it is low.

\section{REFERENCES}

[1] Aon Hewitt, Aon Global Risk Management Survey 2015.

[2] Asendorpf J.B., Banse R., Mücke D., Double Dissociation Between Implicit and Explicit Personality Self-Concept: The Case of Shy Behavior, "Journal of Personality and Social Psychology", 2002, Vol. 83, No. 2.

[3] Bandura A., Self-Efficacy: The Exercise of Control, Freeman, New York 1997.

${ }^{40}$ W. Strus, J. Cieciuch, T. Rowiński, Kołowy model struktury osobowości w ujęciu Lewisa Goldberga, „Studia Psychologica” 2011, 11, 2, 65-93.

${ }^{41}$ M. Łaguna, K. Lachowicz-Tabaczek, I. Dzwonkowska, Skala samooceny SES Morrisa Rosenberga - polska adaptacja metody, „Psychologia Społeczna” 2007, t. 202 (04) 164-176. 
[4] Baumeister R.F., Leary M.R., The nature and function of self-esteem: Sociometer theory, "Advances in experimental social psychology" 2000, Vol. 32.

[5] Baumeister R.F., Campbell, J.D., Krueger J.I., Vohs K.D., Does high self-esteem cause better performance, interpersonal success, happiness, or healthier lifestyles?, "Psychological Science in the Public Interest" 2003, 4(1).

[6] Baumeister R.F., Smart L., Boden J.M., Relation of threatened egotism to violence and aggression: The dark side of self-esteem, "Psychological Review" 1996, 103.

[7] Baumeister R.F., Tice D.M., Hutton D.G., Self-presentational motivation and personality differences in self-esteem, "Journal of Personality" 1989, 57

[8] Bosson J.K., Assessing self-esteem via self-reports and nonreactive instruments: Issues and recommendations [w:] M. Kernis (Ed.), Self-esteem issues and answers: A sourcebook of current perspectives, Psychology Press, Londyn 2006.

[9] Bosson J.K., Swann W.B., Jr., Pennebaker J.W., Stalking the perfect measure of implicit self-esteem: The blind men and the elephant revisited?, "Journal of Personality and Social Psychology" 2000.

[10] Campbell J.D., Lavallee L.F., Who am I? The role of self-concept confusion in understanding the behavior of people with low self-esteem [w:] R.F. Baumeister, Self-esteem. The puzzle of low self-regard, New York: Plenum Press, New York 1993.

[11] Carr A., Psychologia pozytywna. Nauka o szczęściu i ludzkich siłach, Zysk i S-ka, Poznań 2009.

[12] Conner T., Barrett L.F., Implicit Self-Attitudes Predict Spontaneous Affect in Daily Life, "Emotion” 2005, vol. 5 (4).

[13] Costa P.T., McCrae R.R. and Zawadzki B., Strleau J., Szczepaniak P., Śliwińska M., NEO-FFI - Inwentarz Osobowości NEO-FFI, Pracownia Testów Psychologicznych PTP, Warszawa 1998.

[14] Di Paula A., Campbell J.D., Self-esteem and persistence in the face of failure, "Journal of Personality and Social Psychology" 2002, 83.

[15] Dzwonkowska I., Lachowicz-Tabaczek K., Łaguna M., Samoocena i jej pomiar. Polska adaptacja skali SES M. Rosenberga. Podręcznik, Pracownia Testów Psychologicznych PTP, Warszawa 2008.

[16] Egloff B., Schmukle S.C., Predictive validity of an Implicit Association Test for assessing anxiety, "Journal of Personality and Social Psychology" 2002, 83.

[17] Fila-Jankowska A., Samoocena autentyczna. Co ukrywamy sami przed soba, Wydawnictwo Wyższej Szkoły Psychologii Społecznej “Akademica”, Warszawa 2009.

[18] Greenwald A.G., Banaji M.R., Utajone poznanie społeczne: postawy, wartościowanie siebie i stereotypy, „Przegląd Psychologiczny” 1995, 38 (1).

[19] Greenwald A.G., Banaji M.R., Rudman L.A., Farnham S.D., Nosek B.A., Mellott D.S., A unified theory of implicit attitudes, stereotypes, and self-concept, "Psychological Review" 2002, 109.

[20] Greenwald, A. G., Farnham, S. D. (2000). Using the Implicit Association Test to Measure Self-Esteem and Self-Concept. Journal of Personality and Social Psychology, Vol. 79, No 6.

[21] Heimpel S.A., Elliot A.J., Wood J.V., Basic personality dispositions, self-esteem, and personal goals: An approach-avoidance analysis, "Journal of Personality" 2006, 74, 1293-1319. 
[22] Higgins E.T., Self-discrepancy: A theory relating self and affect, "Psychological Review" 1987, Vol. 94(3).

[23] Higgins E.T., Roney C.J.R., Crowe E. \& Hymes C., Ideal versus ought predilections for approach and avoidance distinct self regulatory systems, "Journal of Personality and Social Psychology" 1994, 66(2).

[24] Izdebski P., Żbikowska K., Kotyśko M., Przegląd teorii aprobaty społecznej. Acta Universitatis Lodziensis, „Folia Psychologica” 2013, 17.

[25] Karyłowski J., $O$ dwóch typach altruizmu, Polska Akademia Nauk. Zakład Psychologii, Wrocław, Zakład Narodowy im. Ossolińskich, Wrocław 1982.

[26] Lachowicz-Tabaczek K., Śniecińska J., Intrapsychiczne źródła samooceny: znaczenie emocji, temperamentu i poczucia zdolności do działania, „Czasopismo Psychologiczne” 2008, 2.

[27] Leary M.R., Sociometer theory and the pursuit of relational value: Getting to the root of self-esteem, "European Review of Social Psychology" 2005, 16.

[28] Leising D., Borkenau P., Zimmermann J., Roski C., Leonhardt A., Schütz A., Positive selfregard and claim to leadership: Two fundamental forms of self-evaluation, "European Journal of Personality" 2013, Eur. J. Pers. 27: 565-579, DOI: 10.1002/per.1924

[29] Łaguna M., Lachowicz-Tabaczek K., Dzwonkowska I., Skala samooceny SES Morrisa Rosenberga - polska adaptacja metody, „Psychologia Społeczna” 2007, t. 202 (04).

[30] Łukaszewski W., Struktura ja a działanie w sytuacjach zadaniowych: empiryczne studium nad funkcjami osobowości. Acta Universitatis Wratislaviensis, No 415, Wydaw. Uniwersytetu Wrocławskiego, Wrocław 1978.

[31] Matczak A., Martowska K., PROKOS - Profil Kompetencji Społecznych, Pracownia Testów Psychologicznych PTP, Warszawa 2013.

[32] Oleś P.K., Wprowadzenie do psychologii osobowości, Wydawnictwo Scholar, Warszawa 2008.

[33] Reece B., Brandt R., Howie K (2010), Effective Human Relations: Interpersonal and Organizational Applications

[34] Reykowski J., Kochańska G., Szkice z teorii osobowości, Wiedza Powszechna, Warszawa 1980.

[35] Reykowski, J., Owczynnikowa, O.W., Obuchowski, K. (red.), Studia z psychologii emocji, motywacji i osobowości, Zakład Narodowy im. Ossolińskich, Wrocław.

[36] Rosenberg M., Society and the adolescent self-image, Princeton University Press, Princeton 1965.

[37] Rudolph A., Schröder-Abé M., Riketta M., Schütz A., Easier when done than said! Implicit self-esteem predicts observed or spontaneous behavior, but not self-reported or controlled behavior, "Journal of Psychology” 2010, 218.

[38] Spalding L.R., Hardin C.D., Unconscious unease and self-handicapping: Behavioral consequences of individual differences in implicit and explicit self-esteem, Psychological Science" 1999, 10

[39] Strelau J., (ed.), Psychologia. Podręcznik akademicki, t. I, GWP, Gdańsk 2000.

[40] Strelau, J., Doliński D. (ed.), Psychologia akademicka. Podręcznik, Vol. I, GWP, Gdańsk 2015.

[41] Strelau J., Doliński D. (ed.), Psychologia akademicka. Podręcznik, Vol. II, GWP, Gdańsk 2015.

[42] Strus W., Cieciuch J., Rowiński T., Kołowy model struktury osobowości w ujęciu Lewisa Goldberga, ,Studia Psychologica” 2011, 11, 2. 
[43] Szpitalak M., Polczyk R., Samoocena. Geneza, struktura, funkcje i metody pomiaru, Wydawnictwo Uniwersytetu Jagiellońskiego, Kraków 2015.

[44] Tice D.M., The social motivations of people with low self-esteem [w:] R.F. Baumeister (ed.), Self-esteem. The puzzle of low self-esteem, Plenum Press, New York 1993.

[45] Wojciszke B., Struktura “ja”, wartości osobiste a zachowanie, Ossolineum, Wrocław 1986.

\section{SAMOOCENA MENEDŻERA \\ W ŚWIETLE BADAŃ DEKLARATYWNYCH}

Artykuł stanowi wstęp do szerszego projektu badawczego, którego celem jest analiza samooceny menedżerów w kontekście ich osobowości, uwarunkowań kompetencji poznawczych i społecznych. Odpowiednia samoocena ma kluczowe znaczenie dla skuteczności menedżerów. Istnieją znaczne różnice pomiędzy wysoką i niską samooceną pod względem wytrwałości i poziomu aktywności. Osoby z wysoką samooceną stają wobec otwartych wyzwań, podczas gdy osoby z niską samooceną są zorientowane przede wszystkim na unikanie porażki. Poczucie własnej wartości wiąże się również ze skłonnością do ryzyka oraz $\mathrm{z}$ podejmowaniem decyzji w zarządzaniu. Mimo że jest ona przedmiotem badań od ponad stu lat, dostępnych jest zaledwie kilka niezawodnych narzędzi pomiarowych.

W prezentowanym badaniu podjęto próbę określenia, które zmienne osobowościowe i kompetencji społecznych są znaczącymi predyktorami samooceny. Próbę badawczą stanowili menedżerowie pracujący w korporacjach lub w sektorze MSP. Wykorzystano Skalę Samooceny Rosenberga, NEO-FFI (czynniki osobowości) autorstwa Costy, McCrae i Profil Kompetencji Społecznych PROKOS Matczak i Martowskiej. Odkryto krzywoliniową relację między poczuciem własnej wartości a wiekiem. Wbrew oczekiwaniom kobiety nie osiągnęły wyższego poziomu samooceny niż mężczyźni. Hierarchiczna analiza regresji krokowej ujawniła neurotyczność jako główną i społeczną zaradność jako wtórną istotną zmienną wyjaśniającą samoocenę u polskich menedżerów.

Słowa kluczowe: jawna i utajona samoocena, menedżerowie, Polska.

DOI: $10.7862 /$ rz.2017.hss.43

Przestano do redakcji: wrzesień 2017 r.

Przyjęto do druku: wrzesień 2017 r. 